\title{
Development of Interactive Health Promotion Application Media Based on the "Hygiene Sanitation Vs Covid-19" Quiz and News Up Date as a Form of Corona Virus Prevention in Malang City Adolescents
}

\author{
Dewi Khoirun Nikmatus Z. ${ }^{1}$, Djoko Kustono², Muhammad Al-Irsyad ${ }^{3},{ }^{*}$ \\ ${ }^{1}$ Public Health Departement, Faculty of Sport Science, Universitas Negeri Malang, 64145, Indonesia \\ ${ }^{2}$ Mechanical Engineering Departement, Faculty of Engineering, Universitas Negeri Malang, 64145, Indonesia \\ ${ }^{3}$ Public Health Departement, Faculty of Sport Science, Universitas Negeri Malang, 64145, Indonesia \\ *Corresponding author. Email: muhammad.irsyad.fik@um.ac.id
}

\begin{abstract}
COVID-19 is a new type of virus with hight infectious rate. The prevalence rate of this virus in international scale in 2020 for Indonesia reaches 34th in the world and case fatality rate (CFR) for Indonesia is 3.96. Malang City has been included in the red zone since the pandemic beginning, considering that Malang is a tourism city and also a city with lots of migrants. Currently, the most effective way to prevent COVID-19 is the application of hygienic sanitation. The application of sanitary hygiene is not well conveyed, especially to adolescents who have high mobility and unstable emotion. The delivery of information about this has not been supported by an optimal product, so it is necessary to have a product that is suitable to the needs and limitations of the target. Products that can be developed are Android-based applications. The purpose of this development is as an educational effort to prevent corona virus in Malang City adolescents. This research and development modified the model of Sugiyono, which consists of: (1) potential problems; (2) situation analysis; (3) product design; (4) product design validation; (5) product design revisions; (6) small group trials; (7) product revision I; (8) large group trials; (9) product revision II; (10) final production. Validation by media experts obtained results $72,7 \%$, validation by material experts obtained results $76 \%$. The results of the small group trying $96,7 \%$ and large group get results $96,6 \%$, so it can be concluded that this product is suitable as a healthy support to prevent COVID-19. Further research is to find out the effect of giving interactive application to health behavior and knowladge about hygiene sanitation. It is also hoped that the application can be developed into another application like iOS.
\end{abstract}

Keywords: android aplication, COVID-19, hygiene, sanitation

\section{INTRODUCTION}

2019-nCoV or which is often called Corona Virus Disease 2019 (COVID-19) is a respiratory infection disease that first appeared in Wuhan, Hubei Province, China [1]. On January 7, the CDC (Centers for Disease Control and Prevention) identified the findings of a new type of corona virus which was later named 2019-nCoV [2]. This virus is called a new type because of its composition which is a genetic recombination of the virus or a revolutionary form of the virus in the same family as the cause of MERS-CoV (Middle east respiratory syndrome coronavirus) and SARS-CoV (Severe acute respiratory syndrome coronavirus) [3].
The last data reported until April 1, 2020 at 2:55:50 pm, this virus has even spread to 203 countries and the total number of cases has reached 750,890 positive cases and 36,405 deaths, with a CFR (Case Fatality Rate) of $4.85 \%$ [3]. Meanwhile, the number of cases in Indonesia is in the 34th position in the world rankings and the third highest CFR in the world with a CFR of $9.36 \%$. It means that the mortality rate is very large compared to other countries. There were 1,677 positive cases reported, 103 recovered and 157 died in 32 provinces [4]. Following up on this increasing number of cases, on March 31, 2020 President Jokowidodo announced a public health emergency status [5]. East Java Province with 103 positive cases is in the fourth rank after DKI Jakarta (808), West Java (220) and Banten (152) [4]. Malang 
City has high risk in transmission of corona virus because Malang City is a city that has a promising orientation for migrants, whether for work, school or shopping [6]. In 2018 alone there were 3,795,229 domestic tourists and 124,267 foreign tourists who came to Malang City, this shows that Malang is a city with a lot of migrants so that the possibility of disease spreading is also high [7]. In addition, Malang City is at an altitude of 440-667 masl with an average temperature of $21.6^{\circ} \mathrm{C}-24.7^{\circ} \mathrm{C}$ or classified as cool with high rainfall, this is certainly beneficial for viruses to survive longer [8].

Common symptoms of this virus at baseline were fever (40 [98\%] of 41 patients), cough (31 [76\%]), and myalgia or fatigue (18 [44\%]); Less common symptoms are sputum production (11 [28\%] of 39), headache (three [8\%] of 38), hemoptysis (two [5\%] of 39), and diarrhea (one [3\%] of 38). ), then at a later stage it can cause acute respiratory syndrome to heart injury to death [9]. In general, all age groups are susceptible to infection. Moreover, the adolescents group is important to be noted, eventough they have good immune system, but they have high mobility that's mean they have higher risk in spreading covid-19, and when they don't realize it, they can pass it on to their parents and also other vulnerable people [10][11].

The transmission of this virus also depends on the effectiveness of control measures and the extent of affected areas in adopting hygiene and healthy living habits that can reduce the risk of contracting the disease [9]. Prevention efforts that can be carried out by the community include washing hands with soap for at least 20 seconds, avoiding touching the eyes, nose and mouth using unwashed hands, covering the nose when sneezing, cleaning surfaces with disinfectants and much more [11], [12]. This means that hygiene and sanitation are effective preventive measures that need to be practiced by the community.

Control measures that can be taken by the government are through health promotion, financial assistance, and policies. Health promotion is carried out by the government in order to improve a clean and healthy lifestyle in the community. In this digital native generation, the pattern of information search and promotion carried out tends to depend on communication technology using an internet connection [13]. Education is also a form of promotion that can be applied. The existence of this 4.0 technological advancement allows the development of android-based model applications in the health sector [14]. Based on research it shows that the use of mobile and internet application-based technology has proven to be effective in increasing knowledge and also awareness of community behavior [15].

The news about COVID that is dynamic become a challenge in delivering health information on COVID-19. Print media certainly cannot be a solution to this because it is permanent. The android application is a platform that allows news to be loaded up to date which functions to facilitate the delivery of information. Apart from being in the form of news, health promotion is also carried out using quizzes. As Wardani stated, the method of delivering information using quizzes can encourage interest or target initiative because of its interactive form, besides that it also directs application users in a series of exercises to increase insight without being overwhelmed [16]. Quizzes also can be used as a reflection of the material that has been provided in the application in the form of a booklet, thus helping users to conduct selfassessment of the information they understand. Quizzes also function in enriching knowledge through the questions displayed and also the facts that appear after answers.

In this study, the research targets are adolescents, considering that attention to this age group is still minimal. Adolescents are also a group that is still in the stage of searching for identity, where the unstable nature is still found so that a valid source of information is needed to strengthen their knowledge. Teens who live in Malang City become the researchers' aim of seeing the urgency of Malang City in this pandemic emergency. Researchers also distributed applications with data sources that had been validated so that they could be updated automatically. Based on the background, the researchers conducted research on "Development of Interactive Health Promotion Application Media Based on Quiz 'Sanitation Hygiene Vs Covid-19' and News UpDate as a Form of Corona Virus Prevention in Malang City Adolescents".

\section{METHOD \\ 2.1. Types of Research}

This study is research and development type. Research and development is also the stage of creating a new product or product innovation so that it can be justified [17]. The purpose of research and development is not to test a theory but to develop an effective product so that it can be useful for a particular institution [18]. 


\subsection{Model of Research and Development}

The model of this research was developed by Sugiyono. This model is a procedural model, which is descriptive with certain steps to produce a product (17). Sugiyono method was chosen because this model contains validation and revision so the result of the product can be tested. This method consists of 10 steps, namely: (1) potential problems; (2) situation analysis; (3) product design; (4) product design validation; (5) revision of product design; (6) small group trials; (7) product revision I; (8) large group trials; (9) product revision II; (10) final production [19].

\subsection{Procedural of Research and Development}

The method used in this research and development refers to Sugiono according to the needs of the researcher [19], namely:

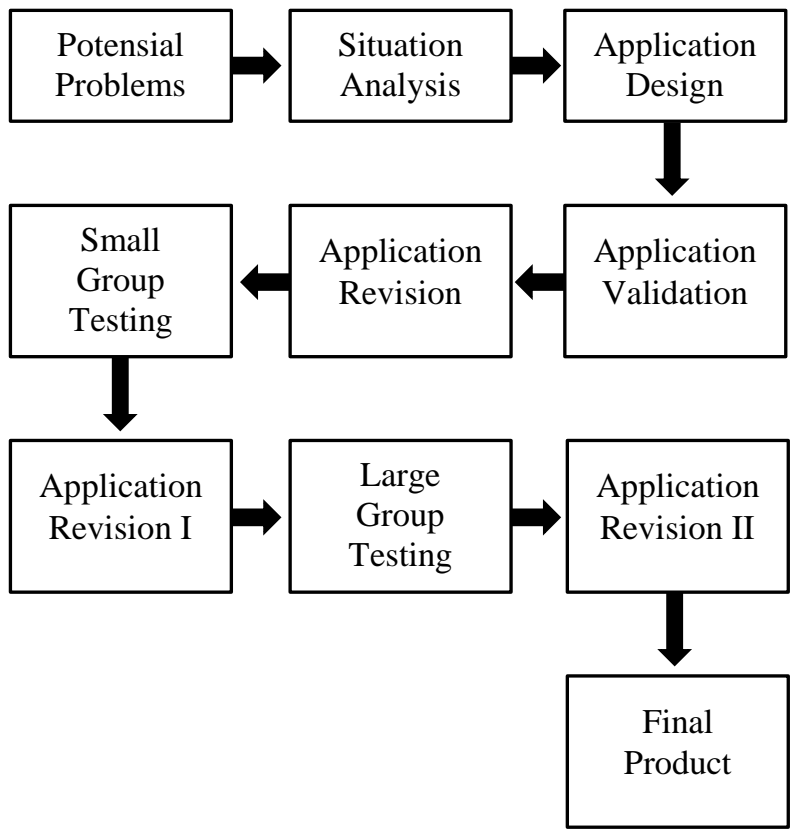

Figure 1. Procedural Research and Development by Sugiyono

\subsubsection{Potensial Problems}

At this stage the researcher explores potential problems based on literature studies. Literature study is a finding or previous research related to the thing being researched. The literature study carried out includes the topic of COVID-19 health. The last data reported until April 1, 2020 at 2:55:50 PM in China as the center of distribution is 82,308 (18). This virus has even spread to 203 countries including Indonesia with the third highest
CFR in the world with a CFR of $9.36 \%$. This virus certainly has the potential to cause higher mortality over time if it is not handled more responsibly.

\subsubsection{Situation Analysis}

The existence of this pandemic has made the developer conduct a situation analysis through secondary data because field observations are not possible. Data from Malang City Government in October 11, 2020, there were 1870 positive cases or were included in the orange zone. This is lower when compared to Malang Regency which is in the yellow zone. Currently the government of Malang city is also targeting Malang City to enter the Yellow zone. So that more efforts are needed in health promotion. The form of electronic media is currently being intensively developed by the government, as evidenced by the fact that on October 8, 2020, Malang City received an award from the Indonesian award 2020 for the category of based economic recovery Ecommerce. So that electronic-based health promotion media also can be applied as an up to date and interesting media.

\subsubsection{Application Design}

Application design is carried out after knowing the potential problems and also analyzing the situation. The application design will be designed depand on the table follows:

Table 1. Product Design

\begin{tabular}{|c|c|}
\hline $\begin{array}{l}\text { Product } \\
\text { Design }\end{array}$ & Product Design \\
\hline \multicolumn{2}{|r|}{ General Design } \\
\hline Background & $\begin{array}{l}\text { There is no up to date health promotion } \\
\text { media which is important role in the } \\
\text { spreading of the COVID-19 hoax in } \\
\text { Malang. }\end{array}$ \\
\hline Theme & The hygiene sanitation Vs COVID-19 \\
\hline $\begin{array}{l}\text { Respondents } \\
\text { (target) }\end{array}$ & $\begin{array}{l}\text { Small group trial: } 6 \text { Malang City } \\
\text { teenagers by random sampling; Large } \\
\text { group trial: } 50 \text { Malang City teenagers }\end{array}$ \\
\hline Purpose & $\begin{array}{l}\text { To convey information related to COVID- } \\
19 \text { and prevent hoaxes spreading. }\end{array}$ \\
\hline Title & Jagoan Covid \\
\hline $\begin{array}{l}\text { Supporting } \\
\text { products }\end{array}$ & $\begin{array}{l}\text { Application design through software, } \\
\text { developers and servers }\end{array}$ \\
\hline \multicolumn{2}{|r|}{ Application Components } \\
\hline Loading page & Waiting screen before going to display \\
\hline Main menu & $\begin{array}{l}\text { a. Distribution data } \\
\text { b. E-booklet } \\
\text { c. Quiz }\end{array}$ \\
\hline
\end{tabular}




\begin{tabular}{|l|l|}
\hline \multicolumn{1}{|c|}{$\begin{array}{c}\text { Product } \\
\text { Design }\end{array}$} & \multicolumn{1}{c|}{ Product Design } \\
\hline & $\begin{array}{l}\text { d. Hoax buster } \\
\text { e. Web link } \\
\text { f. News update }\end{array}$ \\
\hline Exit page & $\begin{array}{l}\text { Contains a statement whether it is true to } \\
\text { close the application }\end{array}$ \\
\hline \multicolumn{2}{|c|}{ Accessibility } \\
\hline Admin & $\begin{array}{l}\text { Management of COVID-19 distribution } \\
\text { data, partner links, hoax buster data and } \\
\text { quizzes }\end{array}$ \\
\hline User & $\begin{array}{l}\text { View data on the distribution of COVID- } \\
\text { 19, access partner links, play quizzes and } \\
\text { search in hoax buster }\end{array}$ \\
\hline Distribution & $\begin{array}{l}\text { Data Contains confirmation data, death } \\
\text { and recovery COVID-19 }\end{array}$ \\
\hline News & $\begin{array}{l}\text { Contains the following materials: } \\
\text { a. Cover } \\
\text { b. Foreword } \\
\text { c. Table of contents } \\
\text { d. Definition of COVID-19 } \\
\text { e. Transmission, signs and symptoms } \\
\text { f. Diagnosis } \\
\text { g. Prevention } \\
\text { h. Management } \\
\text { i. Disinfection guide } \\
\text { j. Environmental Health and food during } \\
\text { a pandemic } \\
\text { k. Bibliograph }\end{array}$ \\
\hline About the \\
application
\end{tabular}

\subsubsection{Application Validation}

Application validation is one of the way in assessing the feasibility of a product, validation is carried out by experts who are competent and master in their fields. This product validation process involves material experts and media experts with the right qualifications so that their suggestion can be used as product improvement. The assessment scale used check list on the validator sheet with Likert scale type, which is an assessment of five categories ranging from very good with a score of 5 and very poor with a score of 1 .

\subsubsection{Application Revision}

The results of expert validation used as input to improve the application. Improvements can be seen from the suggestions and criticism column and application eligibility figures. The aim of this phase is the product can be corrected before testing in small groups.

\subsubsection{Small group trials}

Small group trials were carried out by researcher in group of adolescents who were taken by purposive sampling depand on the criteria that similar to the main target group, some of the criterias are their residence in Malang City, their age are between 12-24 and they want to install the application. Researchers conducted small group trials on 6 teenagers in Malang City. The determination of this amount refers to Setyosari's research, namely the range of respondents between 6-8 people selected according to the criteria of the researcher. Before the trial was carried out, the researcher explained the purpose of the study then provided a file containing the application and also a google form related to assessment and also criticism and suggestions. The result of this phase can be seen reseracher email.

\subsubsection{Revision I}

Application Criticism suggestions based on small group trials are used in product improvement (Applications). If the test results show the product is good, there is no need for revision. However, if there are still some shortcomings, researchers need to revise them.

\subsubsection{Large Group Trial}

The trial subjects were taken by quota sampling with the inclusion criteria of adolescents aged 12-24 years who live in Malang, both male and female, willing to fill out a questionnaire and install an application. The selection of a sample quota of 50 people is based on Uma now in his book Reserch Methods for Business states that if the sample size should be between 30-500 elements.

\subsubsection{Revision II}

After conducting trials in large groups, the feasibility results obtained from the media. If the results show that it is good, there is no need for revision. However, if there are still insufficient values and input, it is necessary to revise the application.

\subsubsection{Final Production}

After the second stage of the revision, the final production is the final output of this research and 
development. Because it is a .apk consistency file, the final production is marked by uploading the application to the google aps store for its usefulness

\subsection{Data Analysis Techniques}

The data obtained based on revisions by experts is qualitative data from the criticism and suggestions column, this data is used as input in the revision. Meanwhile, quantitative data were obtained from an assessment questionnaire by experts, small groups and large groups. Then the data is processed to obtain a product eligibility level. The results of the product assessment are recapitulated then the average value is sought, then the value is compared with the expected value or the highest value then multiplied by $100 \%$ to get the percentage of product eligibility. This percentage figure is compared with the interpretation of product eligibility. The following is the calculation formula used.

$$
\text { Hah }=\frac{\text { Tse }}{\text { Tsh }} \times 100 \%
$$

Description:

Hah = The final result of the trial percentage of

Tse $\quad=$ Total score achieved

Tsh $\quad=$ Total score expected

The final result of the trial percentage will be feasible if it is more than $61 \%$. The standard used in the interpretation of product is Sugiyono's research [19]:
Table 2. Quality of Feasibility and Level of Achievement

\begin{tabular}{|c|c|c|}
\hline Qualification & $\begin{array}{c}\text { Achievement } \\
\text { Level }\end{array}$ & Information \\
\hline $81 \%-100 \%$ & Very good & $\begin{array}{c}\text { Very feasible, } \\
\text { without revision }\end{array}$ \\
\hline $61 \%-80 \%$ & Good & $\begin{array}{c}\text { Eligible, without } \\
\text { revision }\end{array}$ \\
\hline $41 \%-60 \%$ & Fairly good & $\begin{array}{c}\text { Not feasible, without } \\
\text { revision }\end{array}$ \\
\hline $21 \%-40 \%$ & Not good & $\begin{array}{c}\text { Not feasible, needs } \\
\text { revision }\end{array}$ \\
\hline$<20 \%$ & Not very good & $\begin{array}{c}\text { Not very feasible, } \\
\text { needs revision }\end{array}$ \\
\hline
\end{tabular}

\section{RESULTS AND DISCUSSION 3.1.Product Feasibility}

\subsubsection{Media Expert Validation}

Application validation by media experts is carried out to determine the feasibility of the product from the side of the media developed for the delivery of material related to adolescents, COVID-19 and its prevention. This media expert validator is Pondok Pesantren Sabilurrasyad information system development team and the IT team Rosana Travel alumni of Universitas Islam Negeri (UIN) Maulana Malik Ibrahim Malang. The results of validation by media experts can be seen in the appendix and for Quantitative data from the results of application validation by media experts are interpreted in Table 3:

Table 3. Results of Validation Application By Expert Media

\begin{tabular}{|c|c|c|c|c|c|c|c|c|c|}
\hline \multirow{2}{*}{ No. } & \multirow{2}{*}{ Elements Rating } & \multicolumn{5}{|c|}{ Value } & \multirow{2}{*}{ Tse } & \multirow{2}{*}{ Tsh } & \multirow{2}{*}{$\%$} \\
\hline & & 1 & 2 & 3 & 4 & 5 & & & \\
\hline 1. & Responsibility & - & - & - & $\checkmark$ & - & 4 & 5 & $80 \%$ \\
\hline 2. & Compatibility of assets with the theme & - & - & - & $\checkmark$ & - & 4 & 5 & $80 \%$ \\
\hline 3. & Completeness of tolls & - & - & $\checkmark$ & - & - & 3 & 5 & $60 \%$ \\
\hline 4. & Main menu design & - & - & - & $\checkmark$ & - & 4 & 5 & $80 \%$ \\
\hline 5. & Design splash screen & - & - & - & $\checkmark$ & - & 4 & 5 & $80 \%$ \\
\hline 6. & Design Exit page & - & $\checkmark$ & - & - & - & 2 & 5 & $40 \%$ \\
\hline 7. & Layout consistency & - & - & - & $\checkmark$ & - & 4 & 5 & $80 \%$ \\
\hline 8. & Use of size font & - & - & $\checkmark$ & - & - & 3 & 5 & $60 \%$ \\
\hline 9. & Use of font types & - & - & - & $\checkmark$ & - & 4 & 5 & $80 \%$ \\
\hline 10. & Color suitability & - & - & - & $\checkmark$ & - & 4 & 5 & $80 \%$ \\
\hline \multirow[t]{3}{*}{11.} & Suitability Background & - & - & - & $\checkmark$ & - & 4 & 5 & $80 \%$ \\
\hline & Total & & & & & & 40 & 55 & \\
\hline & Average & \multicolumn{5}{|c|}{$\frac{\text { Tse }}{\text { Tsh }} \times 100$} & \multicolumn{2}{|c|}{$\frac{40}{45} \times 100$} & $72,7 \%$ \\
\hline
\end{tabular}

Table 3 shows the average percentage result of validation performed by media experts of $72.7 \%$.
Referring to the eligibility quality table and the level of achievement described in Chapter III of table 3.3, the 
results of the validation by media experts on the application are declared "feasible and good" to be used. The lowest percentage in the assessment above is $40 \%$ on the exit page indicator, so that notes related to revisions for the next stage are included.

After obtaining quantitative data from the validation results, there are qualitative results. The following is the qualitative data interpreted in table 4:

Table 4. Expert Criticism and Suggestions for Media

\begin{tabular}{|c|c|}
\hline Validators & $\begin{array}{c}\text { Criticism and Suggestions for } \\
\text { Improvement }\end{array}$ \\
\hline \multirow[t]{5}{*}{$\begin{array}{l}\text { The Media } \\
\text { Experts }\end{array}$} & $\begin{array}{l}\text { The color of the button action less } \\
\text { contrasted. }\end{array}$ \\
\hline & $\begin{array}{l}\text { Android icon on the exit notification is the } \\
\text { same as the application }\end{array}$ \\
\hline & $\begin{array}{l}\text { Icon The list icon on the e-booklet is the } \\
\text { same as the initial icon }\end{array}$ \\
\hline & $\begin{array}{l}\text { Back button on details of news and hoaxes } \\
\text { made parallel to the search button }\end{array}$ \\
\hline & $\begin{array}{l}\text { Image on news is displayed according to } \\
\text { source }\end{array}$ \\
\hline
\end{tabular}

\subsubsection{The Validation of Material Expert}

Next validation was carried out by a material expert, who is the lecture of specialization in Health Promotion and Behavioral Sciences (PKIP), majoring in Public Health, State University of Malang. The material expert validator is tasked with conducting an assessment for the feasibility of the product and the suitability of the material presented. Furthermore, the results of validation by material experts and quantitative data from the results of application validation by material experts are interpreted in table 5.

Table 5 shows that the average percentage of validation by material experts is $76 \%$. This result is associated with the quality of the feasibility and the level of achievement that can be said "decent and good" as a support in the delivery of material on the product being developed. The results are also included with notes related to improvements or revisions. The lowest value is $40 \%$ on the material clarity indicator so that it is necessary to fix this. Furthermore, the data obtained is in the form of qualitative data.

Table 5. Results of Application Validation by Material Experts

\begin{tabular}{|c|c|c|c|c|c|c|c|c|c|}
\hline \multirow{2}{*}{ No. } & \multirow{2}{*}{ Element of Assesment } & \multicolumn{5}{|c|}{ Value } & \multirow{2}{*}{ Tse } & \multirow{2}{*}{ Tsh } & \multirow{2}{*}{$\%$} \\
\hline & & 1 & 2 & 3 & 4 & 5 & & & \\
\hline 1. & Completeness of material & - & - & - & $\checkmark$ & - & 4 & 5 & $80 \%$ \\
\hline 2. & Depth of material & - & - & - & $\checkmark$ & - & 4 & 5 & $80 \%$ \\
\hline 3. & Material sequences & - & & - & $\checkmark$ & - & 4 & 5 & $80 \%$ \\
\hline 4. & Clarity of material & - & $\checkmark$ & - & - & - & 2 & 5 & $60 \%$ \\
\hline 5. & Clarity of terms & - & - & $\checkmark$ & - & - & 3 & 5 & $20 \%$ \\
\hline 6. & Suitability of material with objectives & - & - & - & $\checkmark$ & - & 4 & 5 & $80 \%$ \\
\hline 7. & Suitability of games with material & - & - & - & $\checkmark$ & - & 4 & 5 & $80 \%$ \\
\hline 8. & Suitability of images with material & - & - & & $\checkmark$ & - & 4 & 5 & $80 \%$ \\
\hline 9. & Suitability of language with material & - & - & $\checkmark$ & - & - & 3 & 5 & $60 \%$ \\
\hline \multirow[t]{3}{*}{10.} & Balance of content in the media & - & - & - & $\checkmark$ & - & 4 & 5 & $80 \%$ \\
\hline & Total & & & & & & 38 & 50 & \\
\hline & Average & \multicolumn{5}{|c|}{$\frac{\text { Tse }}{\text { Tsh }} \times 100 \%$} & \multicolumn{2}{|c|}{$\frac{38}{50} \times 100 \%$} & $76 \%$ \\
\hline
\end{tabular}

The following is the interpreted qualitative data in table 6 regarding criticism and suggestions from media experts.

Table 6. Expert Criticism and Suggestions for Material

\begin{tabular}{|l|l|}
\hline Validator & \multicolumn{1}{c|}{$\begin{array}{c}\text { Criticism and Suggestions for } \\
\text { Improvement }\end{array}$} \\
\hline $\begin{array}{l}\text { Expert } \\
\text { Material }\end{array}$ & Improvement at PUEBI \\
\cline { 2 - 2 } & $\begin{array}{l}\text { On the use of scuba masks, the sign is } \\
\text { clarified }\end{array}$ \\
\hline
\end{tabular}

\begin{tabular}{|c|c|}
\hline Validator & $\begin{array}{c}\text { Criticism and Suggestions for } \\
\text { Improvement }\end{array}$ \\
\hline & $\begin{array}{l}\text { It is necessary to add footnotes to difficult } \\
\text { terms }\end{array}$ \\
\hline & If it is possible to add photos to the quiz \\
\hline & $\begin{array}{l}\text { Writing citation is not only at the end but } \\
\text { there are in-text citation }\end{array}$ \\
\hline & $\begin{array}{l}\text { Improvements in The e-booklet includes } \\
\text { writing errors for the word "contact:" } \\
\text { "isolation vs quarantine" and writing in the } \\
\text { form of a point that is not appropriate if } \\
\text { using the middle }\end{array}$ \\
\hline
\end{tabular}




\subsubsection{Small Grup Trial}

After validating the experts and making improvements according to the results and the suggestion, then a small group trial is carried out. Small group trials were carried out within 1 day. The respondent of small group trials and large group trials are different, but the characteristics are the same. This trial was carried out on adolescents who live in Malang City. Based on the criteria set by the researcher, 6 students became respondents in this trial with the inclusion criteria, namely 14-24 years old and residing in Malang City. The research was conducted online using watsapp group and sheet using g-form. The assessment sheet on the small group trial can be seen in the attachment and then in table 7 the results of the interpretation of the student assessment results data in the small group trial are explained as follows.

Table 7 shows the average percentage results of the assessment by 6 respondents in the small group trial is $96.7 \%$. So it can be said that the quality of the feasibility and the level of achievement of the book is Pop Up interactive said to be "very feasible and very good" for further development. The lowest percentage lies in the assessment aspects in point 3 and point 4, so that this can be a correction for further improvement. In addition, in table 3.6, other criticisms and suggestions have been explained in accordance with the results of the small group trial submitted by respondents in the forum.

Table 7. Small Group Trial Results

\begin{tabular}{|c|c|c|c|c|c|c|}
\hline \multirow{2}{*}{ No. } & \multirow{2}{*}{ Aspects of Assessment } & \multicolumn{2}{|c|}{ Value } & \multirow{2}{*}{ Tse } & \multirow{2}{*}{ Tsh } & \multirow{2}{*}{$\%$} \\
\hline & & Yes & No & & & \\
\hline 1. & The application is easy to use & 6 & 0 & 6 & 6 & $100 \%$ \\
\hline 2. & The language used is easy to understand & 6 & 0 & 6 & 6 & $100 \%$ \\
\hline 3. & The images used are attractive & 5 & 1 & 5 & 6 & $83,3 \%$ \\
\hline 4. & The colors used are attractive & 5 & 1 & 5 & 6 & $83,3 \%$ \\
\hline 5. & The material in the application is interesting & 6 & 0 & 6 & 6 & $100 \%$ \\
\hline 6. & The letters used are easy to read & 6 & 0 & 6 & 6 & $100 \%$ \\
\hline 7. & Quiz presented is interesting for me to play & 6 & 0 & 6 & 6 & $100 \%$ \\
\hline 8. & News updates in the application help me & 6 & 0 & 6 & 6 & $100 \%$ \\
\hline 9. & The material in the e-booklet is coherent & 6 & 0 & 6 & 6 & $100 \%$ \\
\hline \multirow[t]{3}{*}{10.} & $\begin{array}{l}\text { I excited to maintain sanitary hygiene after reading the e-booklet in the } \\
\text { application }\end{array}$ & 6 & 0 & 6 & 6 & $100 \%$ \\
\hline & Total & & & 58 & 60 & \\
\hline & Average & \multicolumn{4}{|c|}{$\begin{array}{l}\frac{\text { Tse }}{\text { Tsh }} \times 100 \% \\
\frac{58}{60} \times 100 \%\end{array}$} & $96,7 \%$ \\
\hline
\end{tabular}

After interpreting the quantitative data, then interpreting the qualitative data obtained from the respondents' criticism and suggestions. The following is the qualitative data that is interpreted in table 8

Table 8. Criticism and Suggestions for Small Group Trials

\begin{tabular}{|c|c|}
\hline Assessors & $\begin{array}{c}\text { Criticism and Suggestions for } \\
\text { Improvement }\end{array}$ \\
\hline \multirow{2}{*}{$\begin{array}{l}6 \text { respondents in } \\
\text { trials small } \\
\text { group }\end{array}$} & There is a writing error in the quiz \\
\hline & $\begin{array}{l}\text { Application can only be used on } \\
\text { Android }\end{array}$ \\
\hline
\end{tabular}

\subsubsection{Large Group Trials}

After small group trials were carried out, the trials were carried out on a broad range of respondents. This trial was carried out for 2 days. Based on the criteria set by the researcher, 50 respondents who live in Malang City are obtained. The assessment sheet for large group trials can be seen in the appendix. The following are the results of student assessments in large group trials which are interpreted in table 9 below. 
Table 9. Large Group Trial Results

\begin{tabular}{|c|c|c|c|c|c|c|}
\hline \multirow{2}{*}{ No. } & \multirow{2}{*}{ Aspects of Assessment } & \multicolumn{2}{|c|}{ Value } & \multirow{2}{*}{ Tse } & \multirow{2}{*}{ Tsh } & \multirow{2}{*}{$\%$} \\
\hline & & Yes & No & & & \\
\hline 1. & Easy to use application & 49 & 1 & 49 & 50 & $98 \%$ \\
\hline 2. & The language used is easy to understand & 50 & 0 & 50 & 50 & $100 \%$ \\
\hline 3. & The image used is attractive & 47 & 3 & 47 & 50 & $94 \%$ \\
\hline 4. & The colors used are attractive & 43 & 7 & 43 & 50 & $86 \%$ \\
\hline 5. & The material in the application is interesting & 50 & 0 & 50 & 50 & $100 \%$ \\
\hline 6. & The letters used are easy to read & 49 & 1 & 49 & 50 & $100 \%$ \\
\hline 7. & The quizzes are interesting for me to play & 47 & 3 & 47 & 50 & $94 \%$ \\
\hline 8. & News updates in the application help me & 49 & 1 & 49 & 50 & $98 \%$ \\
\hline 9. & The material in the e-booklet is coherent & 50 & 0 & 50 & 50 & $100 \%$ \\
\hline \multirow[t]{3}{*}{10.} & $\begin{array}{l}\text { I am passionate about maintaining hygiene sanitation after reading the e- } \\
\text { booklet in the application }\end{array}$ & 49 & 1 & 49 & 50 & $98 \%$ \\
\hline & Total & & & 483 & 500 & \\
\hline & Average & \multicolumn{4}{|c|}{$\begin{array}{l}\frac{\text { Tse }}{\text { Tsh }} \times 100 \% \\
\frac{483}{500} \times 100 \%\end{array}$} & $96,6 \%$ \\
\hline
\end{tabular}

Table 9 shows the average percentage rating of 50 respondents in the large group trial that is $96.6 \%$, so it can be said that the quality of the feasibility and the level of achievement of the book is Pop Up interactive "very feasible and very good" for further development. In addition, it can be seen that the lowest percentage lies in the assessment aspects in points 7 and 3, which are $94 \%$. In addition, in table 3.8 other criticisms and suggestions have been explained in accordance with the results of large group trials.

After obtaining quantitative data from the results of student assessments, then qualitative data is obtained from the criticisms and suggestions presented in the forum. The following is the qualitative data that is interpreted in table 10 .

Table 10. Criticism and Suggestion from Large Group Trial

\begin{tabular}{|l|l|}
\hline \multicolumn{1}{|c|}{ Assessors } & \multicolumn{1}{c|}{$\begin{array}{c}\text { Criticism and Suggestions for } \\
\text { Improvement }\end{array}$} \\
\hline $\begin{array}{l}\text { 50 respondents } \\
\text { in large group } \\
\text { trial }\end{array}$ & $\begin{array}{l}\text { 4 respondent give suggestion that is the } \\
\text { application must be in playstore so the } \\
\text { application can be installed easily }\end{array}$ \\
\cline { 2 - 2 } & Link of the referrence can't be access \\
\hline
\end{tabular}

\subsection{Product Revision}

Revision in research and development is a form of improvement for the development of the final product, so that future product improvements can be made. Product revisions are obtained from the results of the assessment of the application by experts and respondents in group trials that come from aspects of the assessment sheet, as well as criticism and suggestions from experts and group trial respondents.

\section{CONCLUSION}

Based on the results of expert validation as well as the results of the assessment in group trials, the average feasibility level of the application product is categorized into the level "very feasible and very good". This is based on the percentage of the media expert's assessment was $72.7 \%$ (feasible and good), the material expert's assessment was $76 \%$ (feasible and good), the assessment in the small group trial was $96.7 \%$ (very feasible and very good), and the assessment in the large group trial was $96.6 \%$ (very feasible and very good). The advantage of this application itself is that it can foster interest in learning, so that the delivery of material or information won't be boring because the application is modified to be more colorful and more interactive and contains many 
functions. The android application presents information on the device and the target is given the opportunity to interact so that it is more attractive to its users. It is hoped that in the future the application can be modified in the form of iOS and its effects can be examined at the level of knowledge and attitude.

\section{AUTHORS' CONTRIBUTIONS}

DKN: concept and design the study, methodology, analysis, writing; DK \& MA: validation, writing review, supervision

\section{ACKNOWLEDGMENTS}

The authors thank Faculty of Sport Science, Universitas Negeri Malang for supporting this study.

\section{REFERENCES}

[1] J. A. Backer, D. Klinkenberg, and J. Wallinga, "Incubation Period of 2019 Novel Coronavirus (2019-nCoV) Infections Among Travellers from Wuhan, China, 20-28 January 2020," Eurosurveillance, vol. 25, no. 5, p. 2000062, 2020.

[2] N. Chen et al., "Epidemiological and Clinical Characteristics of 99 Cases of 2019 novel Coronavirus Pneumonia in Wuhan, China: a Descriptive Study," Lancet, vol. 395, pp. 507-513, 2020.

[3] J. Fan, X. Liu, W. Pan, M. W. Douglas, and S. Bao, "Epidemiology of Coronavirus Disease in Gansu Province, China, 2020," Emerg. Infect. Dis., vol. 26, no. 6, p. 1257, 2020.

[4] Satuan Tugas Penanganan Covid-19, "Peta Sebaran," www.covid.go.id, 2020. [Online]. Available: https://covid19.go.id/peta-sebaran.

[5] I. Ihsanuddin, "Jokowi Tetapkan Status Darurat Kesehatan Masyarakat," kompas.com, Jakarta, p. Nasional, 2020.

[6] N. N. Ekawati, M. S. Soeaidy, and H. Ribawanto, "Kajian Dampak Pengembangan Pembangunan Kota Malang Terhadap Kemacetan Lalu Lintas (Studi pada Dinas Perhubungan Kota Malang)," J. Adm. Publik, vol. 2, no. 1, pp. 129-133, 2014.

[7] Badan Pusat Statistik (BPS) Kota Malang, "Jumlah Wisatawan Domestik dan Macanegara di Kota Malang, 2014-2020," Malang, 2020.
[8] M. M. Anam, "Strategi Ikonik Wisata untuk Memperkenalkan Kota Malang Sebagai Salah Satu Destinasi Wisata Religi,” J. Pariwisata Pesona, vol. 2, no. 2, p. 11, 2017.

[9] C. Huang et al., "Clinical features of patients infected with 2019 novel coronavirus in Wuhan, China," Lancet, vol. 395, no. 10223, pp. 497-506, 2020.

[10] S. K. Kar, N. Verma, and S. K. Saxena, "Coronavirus Infection Among Children and Adolescents," Coronavirus Dis. 2019 Epidemiol. Pathog. Diagnosis, Ther., pp. 71-79, Apr. 2020.

[11] Center for Tropical Medicine Universitas Gadjah Mada, Buku Saku Desa Tangguh Covid-19, Ver. 1 (14. Yogyakarta: Universitas Gadjah Mada, 2020.

[12] Kementerian Kesehatan, Pedoman Pencegahan dan Pengendalian Coronavirus Disease (Covid-19), Juli 2020. Jakarta: Kementerian Kesehatan RI, 2020.

[13] E. A. Fitriarti, "Urgensi Literasi Digital Dalam Menangkal Hoax Informasi Kesehatan Di Era Digital," Metacommunication J. Commun. Stud., vol. 4, no. 2, pp. 234-246, 2019.

[14] A. E. Madda, M. Ramli, and A. Yani, "Aplikasi mHealth 'SIGA' Untuk Pelayanan Kesehatan Masyarakat Umum Berbasis Android," INA-Rxiv, 2019.

[15] D. Faizah, "Gerakan Nasional Sadar Gizi pada Seribu Hari Pertama Kehidupan: Saatnya Memanfaatkan Teknologi Mobile dan Internet," JIMKI J. Ilm. Mhs. Kedokt. Indones., vol. 1, no. 2, pp. 11-14, 2020.

[16] F. Wardani, "Efektivitas Pemberian Kuis Terhadap Hasil Belajar Siswa Kelas XI IPS Pada Mata Pelajaran Ekonomi," J. Pendidik. dan Pembelajaran Khatulistiwa, vol. 5, no. 5, pp. 1-15, 2016.

[17] T. Trianto, Pengantar Penelitian Pendidikan Bagi Pengembangan Profesi Pendidikan dan Tenaga Kependidikan, 1st ed. Jakarta: Kencana Prenada Media, 2010.

[18] H. Darmadi, Metode Penelitian Pendidikan. Bandung: Alfabeta, 2011.

[19] S. Sugiyono, Metode Penelitian Kuantitatif, Kualitatif, dan R\&D, 2nd ed. Bandung: Alfabeta, 2019. 